\title{
Analysis on the Innovation of Teaching Methods and Its Implementation in Colleges and Universities
}

\author{
Li Li, Bai Dongqing, Qiao Xiuting, Xu Hailong \\ Faculty of Fishery Sciences, Tianjin Agricultural University, Tianjin, 300384, China
}

Key words: Colleges and universities; Teaching methods; Innovation; Implementation path

\begin{abstract}
Colleges and universities are not only the important base for the cultivation of innovative talents, but also the important parts of the national innovation system, besides, they play an irreplaceable important role in building an innovative country. Based on the experience of study and practice from the author, this paper analyzed the necessity of the innovation of teaching methods to raise creative talents, then discussed how to establish the innovation system of the open and diverse teaching methods, finally put forward the path to promote the innovation of teaching methods.
\end{abstract}

\section{Introduction}

The teaching method is the organic part of the whole teaching process, which plays an important role in cultivation of innovative talents. The society under the $21^{\text {st }}$ century requires colleges and universities to cultivate innovative talents. The conflict between the old teaching method and modern teaching content, is bound to affect the development of teaching reform, cultivating innovative talents. Therefore, the reform of teaching methods is the world national higher education reform trend. In education, professional setting, curriculum system, teaching content of our university, teaching material construction and so on are very fruitful. But as the reform in teaching methods lag behind other reforms, it directly affects the effectiveness of educational reform. Therefore, innovation Teaching method, cultivating student's innovation spirit and innovation ability, are the important tasks of deepening the teaching reform, improving the quality of education, and realizing the scientific development of higher education in the new era.

\section{The Necessity of the Teaching Methods Innovation for Cultivating Innovative Talents}

\subsection{Innovative teaching method is the objective requirement on building an innovation oriented country}

The construction of an innovative country is an era of higher historical mission. We must innovate the teaching methods in Colleges and Universities, students in active, exploratory learning, arouse the desire of innovation, develop the spirit of doubt, creative thinking training, play innovation potential, cultivate innovation ability.

To construct an innovative country is a major strategic decision concerning the new century modernization construction of our country. Innovative talents are important forces in the construction of an innovative country. The important quality of innovative talents is the strong spirit of innovation and keen innovation thinking. Long term cramming teaching method leads to "obedient education", which suppresses the cultivation of innovative talents in our country. The construction of an innovative country is the Higher educational school's historical mission endued by the times. We must innovate the teaching methods in Colleges and universities so that arouse the desire of innovation, cultivate suspicion spirit, train creative thinking, release innovation potential, cultivate innovative ability in active and exploratory learning atmosphere. 


\subsection{Innovative teaching methods is the urgent need to deepen the reform of teaching in colleges and universities}

Since 1990s, Chinese colleges and universities have made unremitting efforts and explorations in transformation of thought, updating the concept of education, the reform of personnel training mode, researches and adjusting professional structure, catalogue of specialty and professional settings, and in the researches and reforms, such as the professional training targets of every specialties, talents training standards, the professional teaching plans and curriculum structures. All have made obvious achievements. However, the problems existing in educational methods are too restrictive and backward, which limit the teaching effect and improvement of teaching quality. Therefore, to reform as teacher-centered with books as the center of the infused teaching style, to promote the teaching method of university innovation, the quality-oriented Education and ability-oriented education in the process of teaching can be fulfilled; it is an urgent need to optimize the teaching content and curriculum system when deepening the current teaching reform.

\subsection{Innovative teaching method is the trend of higher educational reform in developed countries}

The teaching method reform not only is an attractive research field of modern teaching research in colleges and universities, but also is an important trend of higher educational reform. Since 1980s, along with major changes in the political, economic, population, science and technology and other factors, the developed countries generally changed the teaching ideas, adjusted training goals, emphasized the cultivation of student's ability and creativity, especially the expression emphasized student's analysis, training, understanding and practical ability. Therefore, the reform of the traditional teaching style is simple without imagination, which is imperative. In the late of 1970s, British proposed "ability education", which was widely accepted by many British universities in 1990s. Almost all universities have carried out active exploration and reform, then achieved remarkable results. The "ability education" promoted that students should assume the responsibility of independent learning and ability-training in order to carry out independent, exploratory learning ability, cultivating comprehensive ability to adapt to social life and engaged in practical work. Therefore, breaking the traditional academic and intellectual education shackles, the implementation of the "action learning" has become an important achievement of English teaching methods innovation works.

\section{Establish an Open and Diverse Teaching Method Innovation System}

\subsection{Perfect lecturing teaching is the foundation}

Lecturing teaching is the oldest teaching method in the world, also is currently the commonest teaching method in higher educational schools. The advantages of lecturing teaching are less time-consuming, low cost, high efficiency, and the students can obtain the systematic theory and a large number of knowledge in a very short time. History proves that lecturing teaching is a kind of effective teaching method. Since the its emergence in medieval universities, lecturing teaching is always prosperous. It is predicted that lecturing teaching is still an important part in the future system of teaching methods. Some teachers' senses of responsibility are not strong, and lack investment in teaching; they are unconcern in students, and repeat what the book says. This can stimulate student's learning motivation, activate student's thinking, enhance their imagination and understanding.

\subsection{Open practical education is the focus}

Practice is the source of innovation, practical ability is an important quality of innovative talent. Practice education refers to the basic element used in educational and teaching practices, focusing on a specific purpose of education and teaching work, students experience activities, exploratory application of knowledge in practice. The practice of education is of great significance to learners: from the technical level, practice education can increase the student's mastery of knowledge, improve 
students' practical ability; from the social level, practice education can strengthen students' understanding of the society, and improve their social ability and social responsibility; in the moral level, practice education can enhance students' moral consciousness, and improve the students' morality. The humanistic and social science should explore the way of combination of systematic teaching and learning practice, and strengthen field visits and social investigation; from the "small class" to "big society", we use the theory to solve practical problems and found problems from social practice that need to be solved.

\subsection{Independent research learning is the core}

Research learning has been paid more and more attentions, and has became the main teaching method of comprehensive courses in Europe and the United States. The research learning has a variety of teaching methods of typical learning, such as case teaching method, learning method based on problem solving, teaching method of problem based learning, one of the common features of these methods is to create the reality and similar teaching situation to stimulate and enhance students' interest in learning and working ability; the two is to solve the open problem, cultivate students' learning ability and creativity; the three is to change the teachers and students in the classroom behaviors. Teachers turn from the knowledge exporter into the guider of the students' independent learning, from independent labor converted into a cooperator; the students' attitudes turn from the passive learning of knowledge into active learning, partially realize the identity of the researchers.

\section{Major Measures to Promote the Innovation of Teaching Methods}

\subsection{Attach great importance to college teaching in thinking}

Teaching and research are the two major functions of a university, and as knowledge, talents training base, university should be the first priority in university teaching jobs. But in the actual teaching, universities are always paying attention to scientific research not to teaching. As for the educational reform in colleges and univerities, there are some important requirements of university teaching calls, but generally speaking, teaching was paid less attentions by teachers in colleges and universities compared with research. In fact, some teachers said, there is no conflict between teaching and research. Because the research is a breakthrough from a certain point on the subject, and the teaching system is to teach a lesson comprehensively and overall in thinking. This kind of thinking is also a guide to the development of scientific research, so teaching and research are more of kinds of interactions and mutual supports.

\subsection{Improve the quality of teachers, stimulate the enthusiasm of teachers to participate in teaching methods innovation}

The development of innovation of teaching methods and university teachers are closely related. The use of teaching methods is the external performance of university teachers' inner quality. To promote the innovation of teaching methods, must improve teachers' sense of responsibilities and ideological qualities, and change the concepts of teaching. Teachers should regard cultivation of the motherland builders highly as the sanctity of their own occupation. Teachers treat their teaching works with high responsibilities from the perspectives of society and students. To promote the innovation of teaching methods, teachers must improve their service quality, strengthen the continue learning, and enrich deep and solid knowledge as reserve, learn the latest developments in this major, and integrate the recent research achievements into Teaching. In addition, to promote the innovation of teaching methods, teachers must also improve teaching skills, therefore, teachers should strengthen innovation research on teaching methods, change work habits of reading textbook word by word and the attitude to cope with works; they should explore the law of modern teaching, and actively carry out the reform of teaching methods and experimental results.

\subsection{Actively reform the teaching management system, guide teachers to learn teaching}

The universities should implement flexible management system in the curriculum arrangement, 
monitoring the teaching process, teaching quality evaluation and other aspects, so that can increase the freedom in the activities of teachers' teaching method innovation. Colleges and universities should reform the teacher employment and evaluation system, pay attention to the appraisals on teachers from students, increase the proportion of teaching effect in the work of the assessment by a large margin, and construct favorable atmosphere of esteeming teachers so that can inspire teachers' enthusiasm to carry out teaching reform, earnestly implement the central status of teaching work in colleges and universities. At present, most of the young teachers are from the non normal university graduate and directly stand on the university stage. They not only lack the necessary teaching skills, but also lack appropriate teaching experience.

\subsection{Strengthen the popularization and application of teaching methods}

The lack of teachers' teaching method innovation ability is one of the factors that currently impede innovation teaching methods in colleges and universities in China. The administrative department of education and higher educational schools should take effective measures to strengthen the propaganda on innovation of teaching methods, and carry out works of teaching methods on training, research and promotion so that the front- line teachers could know the training and education of new teaching methods, which enlarges the innovation of teaching methods and benefits students. In this processs, we must remind teachers not to completely follow the teaching methods, instead we encourage and support teachers to flexibly use innovative teaching methods by combining their personal characteristics with the professional disciplines and actual school conditions so that can form the teaching methods with their characteristics.

\section{References}

[1] Wang Linxue, Wu Yubei, Guo Baolong. Cultivation of Innovative Talents With Inquiry Teaching Method [J]. China University of Science and Technology, 2015, (12): 44-47.

[2] Liang Xiaoyi, Zhao Zhenzeng, Xu Chunqu. Restricting Factors of Training Innovative Talents of Colleges and Universities and Countermeasures [J]. Educational Theory and Practice, 2013, (27): 12-14.

[3] Gu Guosheng. Exploration and Practice of Cultivating Innovative Talents in Colleges and Universities [J]. Education Exploration, 2013, (05): 133-134.

[4] Han Jianhua. Problems and Countermeasures in the Cultivation of Innovative Talents in Colleges and Universities of China [J]. Journal of Jiangxi Normal University (Philosophy and Social Science Edition), 2007, (05): 126-129.

[5] Lv Lin, Shi Yanru. Discussion on the Reform of Teaching Methods to Cultivate Innovative Talents [J]. Journal of Mianyang Normal University, 2007, (10): 110-113.

[6] Zhang Lijin. Construction of Innovative Talents Training Mechanism in Colleges and Universities [J]. Journal of Suzhou University, 2007, (03): 125-127.

[7] Liu Zhiyun. Thinking on Cultivating Innovative Talents in Colleges and Universities [J]. Journal of China University of Geosciences (Social Science Edition), 2007, (10): 96-99. 